Kalamatika: Jurnal Pendidikan Matematika

\title{
DEVELOPMENT OF WEB-BASED LEARNING IMPLEMENTATION AND ANDROID APPLICATIONS TO BRING TEACHER CAPABILITY
}

\author{
Reza Kusuma Setyansah ${ }^{1}$, Andria ${ }^{2}$ \\ ${ }^{1}$ Universitas PGRI Madiun, Setiabudi No. 85, Madiun, Indonesia. \\ reza.mathedu@unipma.ac.id \\ ${ }^{2}$ Universitas PGRI Madiun, Setiabudi No. 85, Madiun, Indonesia. \\ andria@unipma.ac.id
}

\begin{abstract}
This study aims to determine the results of the process of developing a web-based e-learning implementation book and an android application, as a way to hone the teaching skills of prospective teachers. The instruments in this study were observation sheets, books, and questionnaires. Based on the achievement of the product, product evaluation is needed including validation of material experts and media experts. The stages in this study with the ADDIE model are (1) analysis, (2) design, (3) development, (4) implementation, and (5) evaluation. The results of this study obtained that the web-based e-learning implementation book and android application have fulfilled (1) Validation data with the average results obtained from the media validation sheet from media experts $93.67 \%$ and 85 material experts, 33\%. (2) seen a positive influence from the results of the post-test with a percentage of $91.68 \%$ and (3) shows the response of prospective teachers after using e-learning books in the main field test showed a percentage of $82.68 \%$ so that they can hone their ability to teach independently.
\end{abstract}

\section{ARTICLE INFORMATION}

\begin{tabular}{lll}
\hline Keywords & & Article History \\
\cline { 1 - 1 } Teaching Ability & & Submitted Jul 17, 2020 \\
E-Learning & & Revised Oct 31, 2020 \\
Books & & Accepted Nov 12, 2020 \\
Android & & \\
\cline { 1 - 2 } Corresponding Author & \\
\hline
\end{tabular}

Reza Kusuma Setyansah

Universitas PGRI Madiun

Setiabudi No. 85 Madiun

Email: reza.mathedu@unipma.ac.id

\section{How to Cite}

Setyansah, R.K., Andria. (2020). Development of Web-Based Learning Implementation and Android Applications to Bring Teacher Capability. Kalamatika: Jurnal Pendidikan Matematika, 5(2), 155-166.

https://doi.org/10.22236/KALAMATIKA.vol5no2.2020pp155-166 


\section{INTRODUCTION}

Facing the COVID 19 pandemic and current digital developments, information needs not only come from one source but through various things. The world of education still relies on conceptual understanding manually. This is felt to be very ineffective because the education world is accelerating the changes that are happening right now, various kinds of solutions related to the discovery of an effective and efficient learning process continue to be made. Today's generation is called the digital generation, the native generation that was born where technology is already in its environment (started in 1990). The generation, completing all their work through the visualization of digital device screens. (Muchsini \& Siswandari, 2018) Digital natives are a new generation of culture that was born from the penetration of aggressive digital technology. The rapid development of technology influences their learning habits and behavior, and as a result, this generation has a unique way of thinking and learning. (Muchsini \& Siswandari, 2020) feel pressured if the learning process is similar to the previous generation.

The process of learning needs to be tailored, how we teach to reach this visual generation. Some students describe their adaptation from independent, technology-based learning to traditional education formats as "powering down" (Puttnam, 2007). One part of human communication media through the process of visual information, which is learned from a variety of learning sources that are dominated by screens and visuals require direction, so that learners are involved and feel directly from what they see with reality. They wanted to experience education — see it, hear it, and create it. Influenced by current culture, their learning modalities were overwhelmingly visual (Riddle, 2009)

Higher Education as one of the spearheads in the development of education in Indonesia has a very important role in the use of technology. Through technology, it is expected to be able to support the achievement of vision and overcome various problems that arise. The number of problems, especially in learning in the classroom, requires an educator to have innovation in overcoming it. No exception in the Mathematics Education Study Program at PGRI Madiun University (UNIPMA), the classic problem in the learning process required student independence is still a major issue that always demands an effective solution. Dependence of prospective teachers to choose a learning model that is centered on the teacher (teacher-centered learning) and friends, and lack of self-confidence is still often found during 
the microteaching learning process.

Current technological advances, especially in the world of Information Technology (IT) can certainly be one of the effective solutions in overcoming the problem of how to teach prospective teachers. Through the use of technology, it is expected to trigger a shift in the shift from a teacher-centered learning paradigm to student-centered learning. So indirectly, it is also expected that it can train student independence in learning and make it have higher selfconfidence. E-learning learning is currently believed to be one of the solutions in increasing student learning independence. (Setyansah \& Suprapto, 2017) revealed that e-learning based learning can have a positive effect on student learning independence in the lecture process and on student achievement, but it must also be supported by several factors, especially in students. In line with this, (Suprapto \& Maharani, 2018)

In the research, development conducted also concluded that "Produced learning tools in the form of lesson plan, students' worksheets and e-learning based media that will be used to foster students' Reliance". This shows that the use of e-learning is felt to be very effective in increasing the independence of learning from students. Thus the results of use in technology in learning are shown in research development from (Setyansah \& Apriandi, 2019) The textbook to be developed is equipped with a video simulation on how to do calculations using MATLAB, so students can learn by themselves doing calculations with a computer. This shows that the use of video simulations can provide learning and doing MATLAB calculations for students. Referring to research (Kariuki; 2019) It was found that access to ICTs and access to electricity had a significant influence on learner's eLearning delivery mode preferences.

Based on the description above, the development of web-based e-learning books and android applications to hone the teaching ability of prospective mathematics education teachers can be used as an alternative to overcome the problem of how to choose and the breadth of selection of learning models and learning activities can be done not only in the classroom, but it can also be done remotely both individually and as a discussion forum.

\section{METHOD}

The subjects of this study were some grade VI students who took microteaching. Data collection techniques included unstructured interviews, observations, and questionnaires (questionnaire), (Sugiyono, 2018). The research model used in this study is the use of the ADDIE Model (Analyze, Design, Development, Implementation, Evaluation). (Siswanto, 
Hilda, \& Azhar, 2019; Tegeh, Jampel, \& Pudjawan, 2015) described as follows:

\section{Stage 1: Analyse}

In this initial stage interviews and observations are conducted, while the next is identifying and analyzing various needs to determine the right problems, solutions and products, including needs analysis, curriculum analysis, subject matter analysis, and analysis of student characteristics.

Stage 2: Design

In the second stage, designing a concept or product design that will be developed along with the associated instruments. This stage includes the preparation of research instruments, making book covers, book frameworks and capturing images of the training / tutorial stages of using Web and Android applications.

\section{Stage 3: Development}

The third stage, developing products in the form of web-based e-learning books and android applications in accordance with the framework of the book that has been made and the preparation of data collection instruments. This stage includes validating research instruments, testing research instruments, and refining the book framework.

Stage 4: Implementation (Implementation)

The fourth stage, implementing products that have been developed in lectures online (in the network). The implementation is carried out by product testing (limited), main field testing, and analysis of learning media data. Analysis of learning media data includes validity analysis, effectiveness analysis, and practicality analysis.

\section{Stage 5: Evaluation}

The final revision of the book framework is based on data obtained at the time of implementation.

The assessment refers to three product validation assessments, namely content, appearance, and language. To find out the overall percentage, (Akbar, 2013) can be found with the average formula as follows:

$$
\mathrm{V}=\frac{\mathrm{v}_{1}+\mathrm{v}_{2}+\cdots+\mathrm{v}_{\mathrm{n}}}{\mathrm{n}}=\cdots \%
$$

The e-learning implementation learning book for prospective teachers is declared valid (good/good enough) if the combined validity results show more than $70 \%$. 


$$
V=\frac{\text { total empirical score }}{\text { total expected score }} \times 100 \%
$$

Practical analysis, the data analyzed to determine the practicality of learning media were obtained from student response questionnaires. Student questionnaire responses use a Likert scale with a checklist method. Tutorial media can meet the criteria of media practicality if it provides criteria $\geq 70 \%$ of students classically give a positive response (Saputro, 2011). If it is less than $70 \%$ then it must make improvements to the learning media based on suggestions given by students.

According to (Apriandi \& Setyansah, 2017) in the research it was found that the application of interactive conceptual based MATLAB simulation media in learning could improve students' understanding of the Linear Equation System, this was supported by research from (Zhang \& Maas, 2019) That increases their ability of programming skills by doing more simulation studies following the examples given by their instructors. (Setyansah, 2018)

One important aspect of MATLAB is the ability to visualize various types of graphs, data and complex functions that can be completed. Seen from this, then the use of the tutorial will be able to visualize the results of the settlement. (Setyansah, Reza Kusuma; Apriandi, 2019) in mathematical computing with the use of MATLAB in the completion of numerical analysis requires assistance in the form of tutorial material.

\section{RESULT AND DISCUSSION}

\section{Analyze Phase}

\section{Requirements Analysis}

Based on the results of direct observation and interviews with microteaching lecturers it was found that the need for innovation in teaching designed by students in microteaching is very necessary because students tend to choose the concept of learning manually and adjustments where online learning is currently used. So, it is very necessary mastery for prospective teachers to master the use of the web and android applications.

\section{Material Analyze}

Microteaching courses are the goal in developing a Web-based E-Learning book framework and Android Application Analysis of the Characteristics of Prospective Teachers

The tendency of prospective teachers to choose the use of manual or conventional 
learning models in online implementation in microteaching lectures.

Based on the data obtained from the need analysis, material analysis and analysis of the characteristics of prospective teachers it can be concluded that the need for teacher candidates' innovation in using the web and android applications. These innovations can be made by prospective teachers by utilizing the development of learning innovations that utilize the web and android applications. Therefore, researchers made a product developed, namely a web-based e-learning book and an android application so that teachers can be used to hone their teaching abilities.

\section{Design Phase}

\section{Research Instrument Compilation}

The instruments used in web-based e-learning book research and android applications include media validation sheets, student response questionnaire sheets, and post test questions. The next step is to validate the research instruments with the aim of measuring whether the instruments that have been made are appropriate for the measurement assessment by the validator.

\section{Book Outline}

The web-based e-learning book framework and android application include the following sections:

a. Preliminaries - book cover, table of contents, introduction.

b. Text Matter - divided into eight parts, namely:

Part 1: Theoretical Basis, Part 2: Technology and Learning Integration, Part 3: Web Introduction, Part 4: Domain and Hosting, Part 5: Softaculous Apps Installer, Part 6: LMS Management, Part 7: Web Conversion to Android Applications, Part 8: Android Application Publication,

c. Postliminaries - Reference and About the Author Making Capture Image Material

Capture Image is made to make it easier for students / prospective teachers to easily understand the usage procedures of using and managing web conversions and android applications, the part containing Capture Image starts in the fourth to the eighth part of the book framework.

\section{Development Phase}


As for the development of web-based e-learning and android applications, it can be seen in Table 1.

Table 1. Display Development of web-based e-learning and android applications

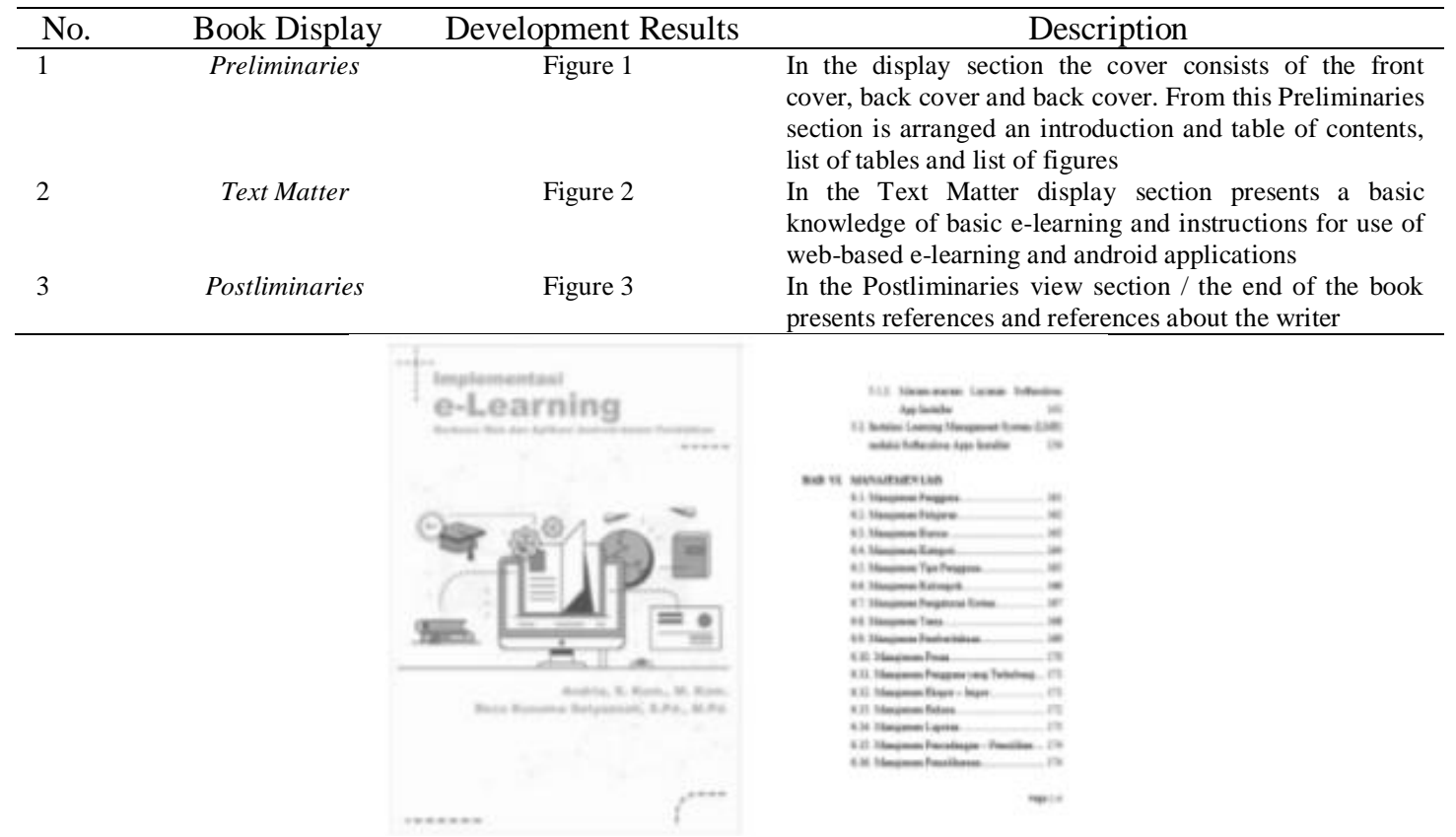

Figure 1. Preliminaries
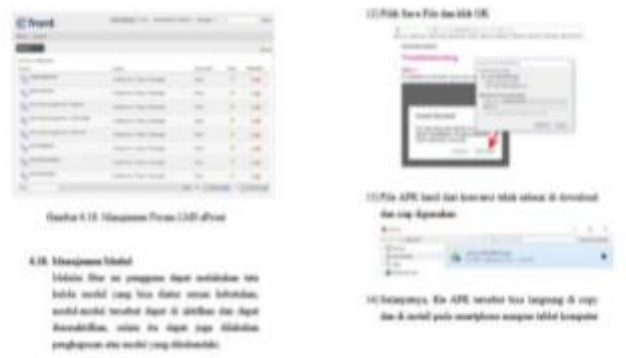

$-\cdots$

$=\cdots$

Figure 2. Text Matter
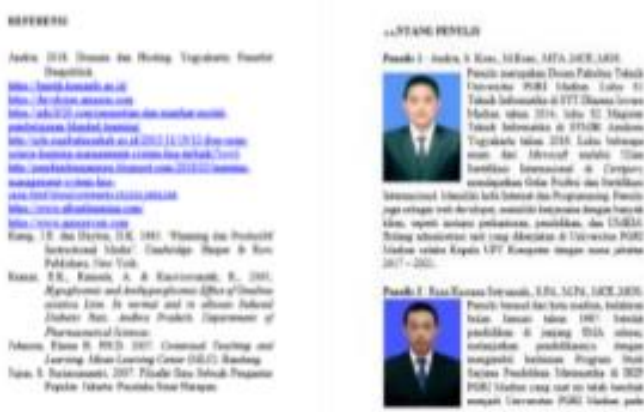

$-$

Figure 3. Postliminaries 


\section{Implementation Phase}

\section{Limited Trial Phase}

The limited trials were conducted on one microteaching group of 6 research subjects. At this stage of the activity, the researcher directs the students as research subjects to read and apply the guidance guides from web-based e-learning books and android applications. In the next stage, the students tried to use the instructions from the book on their computer devices which were carried out at the Mathematics Education Computer Laboratory of UNIPMA. At the end of the application of the book, students are given a response questionnaire to be filled in regarding the application. Student response questionnaire is useful as a tool to see the level of practicality of the developed book. After that, students take part in microteaching activities to see their teaching abilities develop.

\section{Field Test Stage}

The researchers conducted a main field test based on limited trials experiment. The main field test was conducted on three microteaching groups in 19 research subjects. In this activity, equated when the trial is limited and based on the book that has been made.

\section{Analysis of Book Data}

a. Validity Analysis

Book validation sheets that have been validated by several validators are then calculated for their validity. Following are the results of the validation of web-based e-learning books and android applications from several validators based on validity criteria that can be calculated with the formula presented in table 2.

Table 2. The Results of Media Validation by Book Experts

\begin{tabular}{lccc}
\hline & \multicolumn{3}{c}{ Validator (Media Expert) } \\
\cline { 2 - 4 } & I & II & III \\
\hline Empirical Total Score & 92 & 97 & 95 \\
Total Expectation Score & 100 & 100 & 100 \\
Percentage & $92 \%$ & $97 \%$ & $95 \%$ \\
Percentage of Final Validity & & $93,67 \%$ & \\
\hline
\end{tabular}

Table 3. Results of Media Validation by Material Experts

\begin{tabular}{lccc}
\hline & \multicolumn{3}{c}{ Validator (Media } \\
& Expert) & & \\
\cline { 2 - 4 } & I & II & III \\
\hline Empirical Total Score & 85 & 91 & 80 \\
Total Expectation Score & 100 & 100 & 100 \\
Percentage & $85 \%$ & $91 \%$ & $80 \%$ \\
Percentage of Final & & $85,33 \%$ & \\
Validity & & & \\
\hline
\end{tabular}


Based on calculations with formulas, the results of the study are seen in table 2 and table 3 of the validity elements of web-based e-learning books and android applications to hone the teaching abilities of prospective teachers with the average results obtained from the media validation sheet from media experts amounting to $93.67 \%$ and $85.33 \%$ of material experts.

\section{b. Effectiveness Analysis}

The effectiveness sheet of the book is seen from the value of the results of the post-test comprehension done by students after reading the web-based e-learning book and the android application is carried out on a limited trial and main field test. Here are the overall results of the posttest in the main field test

Table 4. Main Field Test Post-test Results

\begin{tabular}{ccc}
\hline $\begin{array}{c}\text { Amount of Score obtained } \\
(\mathrm{T})\end{array}$ & $\begin{array}{c}\text { Total Total Score } \\
(\mathrm{Tt})\end{array}$ & $\begin{array}{c}\text { Percentage of Mastery Learning } \\
(\mathrm{KB})\end{array}$ \\
\hline 1742 & 1900 & $91,68 \%$ \\
\hline
\end{tabular}

Based on the post test results in table 4, it can be concluded that the web-based elearning book and android application meet the mastery achievement comprehension of the book's knowledge of $91.68 \%$. Based on the effectiveness criteria guidelines according to (Sudjana, 2014), it can be concluded that the book was developed into the effective criteria.

c. Practicality Analysis

The practicality of learning media was obtained from the percentage of questionnaire responses that were filled out by semester VI students when the trial was limited and the main field test. Following the results of filling out the student response questionnaire can be calculated with the formula, (Sugiyono, 2018). This can be seen from the results of filling out the response questionnaire outlined in the following two tables with limited test tables and the following field test tables.

Table 5. The Result of Filling Out Questionnaire Response Limited

\begin{tabular}{ccc}
\hline $\begin{array}{c}\text { Total Number of } \\
\text { Scores Obtained (A) }\end{array}$ & Ideal Score (B) & $\begin{array}{c}\text { Percentage of student responses } \\
\text { practicality (P) }\end{array}$ \\
\hline 489 & 600 & $\mathbf{8 1 , 5 0 \%}$ \\
\hline
\end{tabular}

Table 6. Results of Filling in the Field Trial Response Questionnaire

\begin{tabular}{ccc}
\hline Total number of scores obtained (A) & Ideal Score (B) & $\begin{array}{c}\text { Percentage of student responses } \\
\text { practicality (P) }\end{array}$ \\
\hline 1571 & 1900 & $82,68 \%$ \\
\hline
\end{tabular}

From table 5 and 6, it can be concluded that the e-learning book based on web and 
android applications obtained a percentage in a limited trial of $81.50 \%$ and a main field test of $82.68 \%$.

So, it can be concluded that the book that was developed meets the practicality element because the percentage obtained is $\geq 70 \%$ and means students classically give a positive response. (Sugiyono, 2018)

This is in line with (Yadav, Tiruwa, \& Suri, 2017) Internet Based Learning (IBL) in institutions of higher education produces major changes in traditional teaching and learning processes throughout the world. In addition, (Lestari, 2019) shows that web based multimedia teaching Project Based Learning can improve students' mastery of learning because the whole process is interactive and interesting.

\section{CONCLUSION}

Web-based e-learning books and android applications that are developed consist of (1) Preliminaries/Initial Section, (2) Text Matter/Book Content Section, and (3) Postliminary/End Section. From the development of the book, it was stated that it fulfilled the valid, effective and practical criteria. This can be seen from the validity element with the average results obtained from the media validation sheet from media experts at $93.67 \%$ and from material experts at $85.33 \%$. Seen from the positive influence of the results of the post-test with a percentage of $91.68 \%$, and shows the response of prospective teachers after using web-based e-learning books and Android applications on the main field test showed a percentage of $82.68 \%$, so as to hone teaching skills independent.

\section{REFERENCES}

Akbar, S. (2013). Instrumen Perangkat Pembelajaran. Bandung: PT Remaja Posdakarya.

Apriandi, D., \& Setyansah, R. K. (2017). Penerapan Media Simulasi MATLAB Berbasis Interactive Coceptual untuk Meningkatkan Pemahaman Konsep Mahasiswa. Issn, 6(2), 2089-8703.

Kariuki;, E. A.-N. M. G. (2019). Learner access to resources for eLearning and preference for eLearning delivery mode in distance education programs in Ghana. International Journal of Educational Technology, 6(2), 1-9.

Lestari, A. S. (2019). The Development of Web Learning Based on Project in The Learning 
Media Course at IAIN Kendari. Jurnal Pendidikan Islam, 5(1), 39-52. https://doi.org/10.15575/jpi.v5i1.2909

Muchsini, B., \& Siswandari, S. (2018). Digital Natives' Behaviours and Preferences: PreService Teachers Studying Accounting. International Journal of Pedagogy and Teacher Education, 2(2), 355. https://doi.org/10.20961/ijpte.v2i2.24088

Muchsini, B., \& Siswandari, S. (2020). Class Culture And The Academic Stress Of Digital Natives Generations. Jurnal Cakrawala Pendidikan, 39(1), 102-110. https://doi.org/10.21831/cp.v39i1.26910

Puttnam, D. (2007). In class, I have to power down. The Guardian Education, 8(07).

Riddle, J. (2009). Engaging the Eye Generation: Visual Literacy Strategies for the K-5 Classroom. Portland, Maine: Stenhouse Publisher.

Saputro. (2011). Pengembangan Perangkat Pembelajaran Matematika dengan Media Visual Basic Net 2008 pada Materi Lingkaran di Kelas VIIIB MTs Negeri Krian Sidoarjo. Institut Agama Islam Negeri Sunan Ampel Surabaya Fakultas Tarbiyah Jurusan Pendidikan Matematika.

Setyansah, Reza Kusuma; Apriandi, D. (2019). Analisis numerik: pemograman matlab berbasis simulasi e-learning. Yogyakarta: Deepublish.

Setyansah, R. K. (2018). Kalkulus Diferensial lengkap dengan tutorial MATLAB. Yogyakarta: Deepublish.

Setyansah, R. K., \& Apriandi, D. (2019). Development of Textbook Based on E-Learning "Matlab Simulation" in Numerical Analysis. Journal of Physics: Conference Series, 1254(1), 0-6. https://doi.org/10.1088/1742-6596/1254/1/012024

Setyansah, R. K., \& Suprapto, E. (2017). Peningkatan Kemandirian Belajar Mahasiswa Melalui Pembelajaran Berbasis E-Learning Pada Mata Kuliah Kalkulus Differensial. Jurnal Program Studi Pendidikan Matematika, 3(2), 78-90. 
Siswanto, R. D., Hilda, A. M., \& Azhar, E. (2019). Development Combinatorics Realistic Mathematics Education Application based on the Android Mobile. International Journal of Innovation, Creativity and Change, 5(6), 123-140. Retrieved from https://www.ijicc.net/images/vol5iss6/5612_Siswanto_2019_E_R.pdf

Sugiyono. (2018). Metode Penelitian Kuantitatif, Kualitatif, dan R\&D. (Alfabeta). Bandung.

Suprapto, E., \& Maharani, S. (2018). Development of e-learning based media in economic mathematics course to increase student s' reliance, 130-137.

Tegeh, I. M., Jampel, I. N., \& Pudjawan, K. (2015). Pengembangan Buku Ajar Model Penelitian Pengembangan dengan Model ADDIE. Seminar Nasional Riset Inovatif IV, $208-216$.

Yadav, R., Tiruwa, A., \& Suri, P. K. (2017). Internet based learning (IBL) in higher education: a literature review. Journal of International Education in Business, 10(2), 102-129. https://doi.org/10.1108/JIEB-10-2016-0035

Zhang, X., \& Maas, Z. (2019). Using R as a Simulation Tool in Teaching Introductory Statistics. International Electronic Journal of Mathematics Education, 15(1), 599-610. https://doi.org/10.29333/iejme/5773 